DOI: $10.15290 / \mathrm{bsl} .2021 .18 .07$

\author{
Magda Nabiałek \\ Wydział Polonistyki \\ Uniwersytet Warszawski \\ e-mail: magdanabialek@uw.edu.pl \\ ORCID: 0000-0003-2487-5146
}

\title{
Kuglarze w dramat walą. Adam Polewka i szopkowo-farsowe inspiracje w dramaturgii dwudziestolecia międzywojennego
}

Dramaturgia dwudziestolecia międzywojennego nadal nie doczekała się syntetycznego studium, które ujęłoby w ramy naukowego dyskursu szereg przemian, których w tamtym okresie doświadczał polski dramat. Okres ten w polskiej dramaturgii definiuje się najczęściej jako czas głębokiego kryzysu. Niestety, przekonanie to doprowadziło do marginalizacji badań i koncentracji uwagi właściwie jedynie na dokonaniach Witkacego. Z dzisiejszej perspektywy wydaje się, że zupełnie niesłusznie. Mimo że dwudziestolecie nie wydało z siebie nowego polskiego dramatu narodowego (twórczości Witkacego właściwie nigdy tak nie postrzegano), to właśnie $\mathrm{w}$ tym okresie trwały niezliczone poszukiwania nowej formuły dramatu, próby rewizji jego poetyki, modernizacji literatury dramatycznej, sposobu włączenia dramatu na nowo w obszar społecznej dyskusji, jak i ożywienia kontaktu z publicznością.

Szczególne zakorzenienie współczesnej dramaturgii w dwudziestoleciu pokazują publikacje Krystyny Duniec ${ }^{1}$. Karolina Czerska ${ }^{2}$ walczy o odzyskanie pamięci o dokonaniach Cricot I, Lilianna Dorak-Wojtkowska przypo-

\footnotetext{
1 K. Duniec, Dwudziestolecie. Przedstawienia, Warszawa 2017.

2 K. Czerska, Teatr Cricot - suma przybliżen, „Didaskalia” 2019, nr 153, s. 46-54; K. Czerska, Cricot - marzenie o teatrze politycznym? (Fragmenty), w: Polityki Awangardy, red. A. Karpowicz, J. Kornhauser, M. Rakoczy, A. Wójtowicz, Kraków 2021.
} 
mina o niecodziennych dokonaniach Witolda Wandurskiego ${ }^{3}$. To wszystko jednak za mało i nie sposób ustrzec się przed odczuwalnym brakiem syntetyzujących całości. Trudno o nią jednak bez mikrohistorii dramatu, których dalej mamy za mało. Dlatego warto przypomnieć kolejną, marginalizowaną i niedocenianą postać okresu przedwojennego (po wojnie bowiem zajął się głównie działalnością organizacyjną w Związku Literatów Polskich oraz polityczną - jako poseł RP) - Adama Polewkę. Niniejszy artykuł nie ma jednak na celu wyłącznie biograficznej prezentacji sylwetki tego absolutnie wyjątkowego twórcy, a związanie jego postaci z konkretnym nurtem silnie drążącym polską dramaturgię tamtego okresu, jakim było sięganie do inspiracji i tradycji szopki, igrców, komedii dell'arte. Słowem, ludycznej tradycji zaczerpniętej $\mathrm{z}$ folkloru albo do folkloru nawiązującej.

\section{Kuglarz, kopalnia anegdot, komunista}

Adam Polewka (1903-1956), publicysta, tłumacz, pisarz, znany przede wszystkim jako niepokorny współpracownik Józefa Jaremy w Teatrze Artystów Cricot $\mathrm{I}^{4}$ oraz tłumacz średniowiecznej farsy Mistrz Panthelin, jedna z "osobistości” przedwojennego Krakowa, był również aktywnym działaczem komunistycznym, szczerze oddanym sprawie, dla której po 1945 roku poświęcił działalność artystyczną ${ }^{5}$, rozstając się właściwie całkowicie $\mathrm{z}$ teatrem.

Na przełomie lat 20. i 30. Polewka dał się poznać jako bardzo ciekawy prelegent, sprawny reżyser i autor szopek politycznych. Zostawił po sobie niewielki dorobek, w większości w drukach ulotnych, po których ślad zaginął. Tak niestety stało się między innymi z ogromnie ważnymi dla historii samego Cricot I, jak i w ogóle polskiej dramaturgii tamtego okresu, szopkami

\footnotetext{
${ }^{3}$ L. Dorak-Wojakowska, Dramaturg jako archiwista. O stylu montażu dokumentalnego Witolda Wandurskiego... i sceny robotniczej, "Annales Universitatis Paedagogicae Cracoviensis. Studia de Cultura" 2019, nr 11, s. 20-35; Zob. także: K. Duniec, "Śmierć na gruszy”, czyli robotnicy, w: tejże, Dwudziestolecie. Przedstawienia.

4 Jerzy Lau w swojej książce wspomnieniowej poświęconej przedwojennej historii Cricot wielokrotnie przypominał jako to Polewka obiecywał Jaremie gotowe teksty, a potem pracował nad nimi miesiącami, aż w końcu kolejne projekty upadały. Zob. J. Lau, Teatr artystów Cricot, Kraków 1967.

5 Są to oczywiście domysły, nie ma bowiem jednoznacznych świadectw, które tłumaczyłyby powody zaprzestania przez Polewkę aktywnej pracy twórczej. Trzeba jednocześnie przypomnieć, że w okresie powojennym Polewka był bardzo aktywnym członkiem Związku Literatów Polskich.
} 
politycznymi, które Polewka namiętnie tworzył. Fragmenty najsłynniejszej z nich - Herod i Ariowie 6 - często są przywoływane w kontekście podstawowych założeń Cricot. Wiele informacji o działalności samego Polewki przetrwało jedynie we wspomnieniach osób związanych z Cricot I oraz Domem Literatów na Krupniczej ${ }^{7}$. Pewnych informacji dostarcza także powojenny tom Kocham i nienawidzę $e^{8}$ - zbiór felietonów w dużej mierze o charakterze wspomnieniowym autorstwa samego Polewki.

Z teatrem związał się bardzo szybko. W latach 1927-1928 był wykładowcą uniwersytetu ludowego w Szycach. Miał więc okazję obserwować autentyczne narodziny amatorskiego teatru ludowego Zofii Solarzowej ${ }^{9}$. Ideę „butnego oświecicielstwa” starał się sam wprowadzić w Teatrze Robotniczym TUR w Sosnowcu ${ }^{10}$, którym kierował w latach 1929-1930. To tutaj po raz pierwszy dał się poznać jako autor faktomontaży (Sacco $i$ Vanzetti) oraz rewii politycznych (Losy Europy) ${ }^{11}$. Współpracował także przez pewien czas z OM TUR w Krakowie. Celem Polewki, podobnie jak działającego mniej więcej w tym samym czasie Witolda Wandurskiego, było stworzenie prawdziwie nowoczesnej sceny dla mas, która nie będzie jednak przestrzenią dla naiwnych i prostych sztuk, nie będzie także pełnić funkcji tuby agitacyjnej. Scena ta miała natomiast charakter zbliżony do kierowanego przez Władysława Broniewskiego i Stanisława Ryszarda Standego Robotniczego Studia

6 Fragmenty zostały także opublikowane w: A. Polewka, Herod i Ariowie (fragment z szopki „żywych masek”), „Nasz Wyraz” 1938, nr 1.

7 Biografem, jak do tej pory jedynym, Adama Polewki został jego dobry przyjaciel - Juliusz Kydryński. Jego wspomnienie dostarcza wielu ciekawych szczegółów, nie jest jednak także wolne od idealizacji bohatera. Zob. J. Kydryński, Próba portretu (Rzecz o Adamie Polewce), Kraków 1964.

8 Por. A. Polewka, Kocham i nienawidzę, Kraków 1955.

9 Teatr ludowy w dwudziestoleciu międzywojennym rozwijał się bardzo dynamicznie, choć nie bez przeszkód. Z myślą o wsparciu zespołów ludowych, wszelkiego typu oddolnych inicjatyw teatralnych na wsiach powstały dwa czasopisma - we Lwowie wydawano „Poradnik Teatrów i Chórów Włościańskich” (1908-1923), w Warszawie zaś „Teatr Ludowy” (1920-1969). Szczegółowo sposób funkcjonowania tych periodyków omawia D. Fox, Czasopiśmiennictwo teatralne w Polsce w latach 1918-1939, Katowice 2013, s. 50-84.

10 Historię tego ruchu przypomina S. Pol, Ze wspomnień nauczyciela socjalisty, w: PPS - wspomnienia z lat 1918-1939, t. 2, red. J. Cesarski i in., Warszawa 1987.

11 „Mniej znaną i mało opisywaną placówką był Teatr Zagłębia TUR w Sosnowcu, kierowany przez Adama Polewkę w 1929 roku. Był to również teatr robotniczy, amatorski, prowadzony jednakże przy udziale zawodowego reżysera Stanisława Wolickiego. Jego swoiste oblicze określały dwie wystawione sztuki, obie poetyckie: reportaż Polewki Sacco i Vanzetti oraz Sędziowie Wyspiańskiego" [S. Marczak-Oborski, Teatr romantyczny, rewolucyjny, polityczny, „Teksty” 1973, nr 3, s. 61]. 
Teatralnego w Warszawie (1926-1930) ${ }^{12}$. To tutaj właśnie w Galerii Luksemburga Leon Schiller przygotował we współpracy z Tacjanną Wysocką w 1928 roku inscenizację na podstawie fragmentu Słowa o Jakubie Szeli Brunona Jasieńskiego.

W końcu trafił do Cricot I prowadzonego przez Józefa Jaremę. Odzyskiwanie historii Cricot I to osobne wyzwanie, na szczęście wydaje się, że są już badacze, którzy się go podjęli. Obecność w Cricot Adama Polewki jest natomiast jeszcze bardziej niejasna. Wiadomo, że dla teatru mieszczącego się najpierw przy Placu Świętego Ducha w Krakowie, a potem w słynnej kawiarni Plastyków przy Łobzowskiej, tłumaczył m.in. Mistrza Panthelina. Wspólnie z Jaremą stworzył szopkę Herod i Ariowie. Cała reszta to historia pełna poszlak i domysłów wyłaniających się m.in. ze wspomnień osób związanych z Cricot.

Adam Polewka współpracował z PPS, nie krył zupełnie swoich przekonań politycznych i fascynacji komunizmem. Wydaje się, że przekonania te nie pozostały bez wpływu na jego twórczość, mimo że nigdy nie pisał utworów jawnie agitacyjnych. Natomiast ich wywrotowy, rewolucyjny, podważający zastany porządek świata charakter nikogo chyba - kto świadom jest skomplikowania lewicowo nastawionej części twórców tamtego okresu - nie dziwi.

Niewątpliwie jednak Polewkę i pozostałych twórców Cricot ${ }^{13}$ łączyło jedno - przekonanie o społecznym zaangażowaniu teatru, rozumianym jednak przede wszystkim jako kształtowanie gustu widzów, ich świadomości, stosunku do świata ${ }^{14}$. Otaczająca rzeczywistość społeczno-polityczna zmuszała do reakcji, część związanych z Criocot osób była więc m.in. aktywnymi członkami KPP ${ }^{15}$. Artyści ci nie wykorzystywali twórczości do agitacji. Byli świadomi, że przede wszystkim muszą swoim widzom zaproponować inną

12 E. Skowrońska, Wspomnienie o Robotniczym Studio Teatralnym, „Pokolenia”. Biuletyn Komisji Historycznej KC ZMS, Warszawa 1962. Cyt. za: E. i M. Wodnarowie, Polskie sceny robotnicze 1918-1939. Wybór dokumentów i relacji, Warszawa 1974.

13 Warto przy okazji przypomnieć, że z Cricot I sympatyzowali m.in. Tytus Czyżewski, Tadeusz Boy-Żeleński, Leon Chwistek. Współpracowali z Jaremą m.in. Ludwik Puget czy Witkacy, którego Mątwa wystawiona przez Cricot I stała się najważniejszym wydarzeniem w dziejach tego zespołu.

14 Widać to bardzo wyraźnie w publicystycznych wystąpieniach samego Jaremy [J. Jarema, Cricot. O teatrze plastycznym, "Głos Plastyków” 1934, nr 7-8; tenże, Patrzymy na was, "Tygodnik Artystów" 1934, nr 3, tenże, Przed nowym sezonem Cricot, "Nasz Wyraz" 1938, nr 9], współpracującego m.in. przy wystawieniu Mątwy Henryka Wicińskiego - Nowy sezon Cricot w Krakowie, "Gazeta Artystów" 1934, nr 7.

15 Mowa przede wszystkim o Marii Jaremie i Henryku Wicińskim, który za swoje poglądy został relegowany z ASP w Krakowie. 
formę samego widowiska teatralnego. To, że - tak jak w przypadku szopek Polewki - odnosiło się ono również do konkretnych wydarzeń z życia polityczno-społecznego, jest zrozumiałe. Wydaje się jednak, że wykorzystywanie sztuki do komentowania życia publicznego nie stanowiło celu samego $\mathrm{w}$ sobie dla nikogo $\mathrm{z}$ tego środowiska.

Interwencyjny, ale jednocześnie i awangardowy charakter wszystkich tych inicjatyw stanowił o ich niezwykłej sile, a jednocześnie przyczynił się do krótkiego ich trwania. Sam teatr w Sosnowcu bardzo przypominał lewicowe, proletariackie teatry niemieckie i rosyjskie działające $\mathrm{w}$ latach dwudziestych. Najdłużej przetrwał oczywiście Cricot, natomiast nie bez powodu większości odbiorców nazwa ta kojarzy się znacznie bardziej z dokonaniami Tadeusza Kantora. Dzisiaj jednak nie tylko o długu Kantora wobec Cricot I, ale i twórców takich jak Mrożek czy Różewicz trzeba przypominać. Aby to zrobić, trzeba jednak zmienić nieco optykę - z dyskusji skoncentrowanej wyłącznie na społecznym zaangażowaniu, lewicowości, rewolucyjności postaw prezentowanych przez twórców takich jak Polewka przejść na poziom refleksji nad zagadnieniami formy, jaką do realizacji swoich celów artystycznych i pozaartystycznych oni wybrali. Do dyskusji tej prowokuje zaś wstęp, jakim Polewka opatrzył powojenne wydanie zapisu widowiska Igrce w Barbakanie.

\section{W poszukiwaniu (nie)zapomnianej formy}

Adam Polewka to postać szalenie interesująca pod wieloma względami. W tym artykule pojawia się on jednak przede wszystkim jako autor Igrców w Barbakanie ${ }^{16}$. W 1953 roku w Krakowie nakładem Wydawnictwa Literackiego ukazał się zapis widowiska ${ }^{17}$, które Polewka przygotował z okazji Dni Krakowa (był zresztą jednym z inicjatorów tego wydarzenia). Podstawą tego przedstawienia była ludowa twórczość polska oraz spolszczone przez Polewkę „autentyki średniowiecznego pochodzenia głównie francuskiego, fla-

\footnotetext{
16 A. Polewka, Igrce $w$ Barbakanie, Kraków 1953. Pierwotne przedstawienie wystawione już $\mathrm{w}$ roku 1938 nosiło tytuł Igrce w gród wala, natomiast w powojennym wydaniu książkowym Polewka zdecydował się na tytuł Igrce $w$ Barbakanie. Ponieważ w rozważaniach posiłkuję się przede wszystkim wstępem do wydania z 1953 roku, zdecydowałam się na konsekwentne użycie tego drugiego tytułu.

17 Warto dodać, że widowisko to funkcjonowało także pod tytułem Waganci. W 1966 roku pod takim tytułem wystawiono je w Teatrze Dzieci Zagłębia w Będzinie w reżyserii Władysława Jaremy i inscenizacji Jana Dormana (co także wydaje się bardzo ciekawe, w kontekście zainteresowań i inspiracji łączących Polewkę i Dormana). W 1977 roku w Teatrze Polskim w Bielsku-Białej wystawił je Jerzy Ukleja.
} 
mandzkiego i niemieckiego"18. Jest to jeden z niewielu tekstów z okresu dwudziestolecia opatrzony autorskim wstępem, który ujawnia przekonania twórcy. W wielu innych przypadkach tego typu rozważania można rekonstruować jedynie z dyskusji toczących się na łamach czasopism ${ }^{19}$.

Igrce $w$ Barbakanie jak $\mathrm{w}$ soczewce skupiają $\mathrm{w}$ sobie natomiast jedną $\mathrm{z}$ ważniejszych linii rozwojowych dramatu okresu dwudziestolecia. Dramatu, który miał dać zupełnie nową sztukę - otwartą na żywy kontakt z publicznością, o rewolucyjnym, często ludowo-proletariackim charakterze. Studiując wstęp Adama Polewki do Igrców, można próbować odtwarzać motywacje, które prowokowały ogromne zainteresowanie, jakim w latach 20., a szczególnie 30. cieszyły się takie gatunki widowiskowe takie jak farsa, szopka, a także cyrk, rewia czy kabaret.

Zanim jednak przejdę do próby krytycznej lektury wstępu Polewki, podkreślić muszę, że widowisko to zdaje się być punktem dojścia w twórczości niepokornego współpracownika Józefa Jaremy. Polewka od samego początku swojej działalności wyraźnie ujawniał zainteresowanie tego typu widowiskowymi gatunkami dramatycznymi, związanymi z „nażywością”, tradycją improwizacji rodem z komedii dell'arte. Wspominałam już o jego pierwszym faktomontażu (Sacco i Vanzetti) oraz rewii politycznej (Losy Europy). Warto przypomnieć także słynne Otrzęsiny, zrealizowane przez Polewkę na dziedzińcu Collegium Maius w Krakowie w 1935 roku, o zdecydowanie rewolucyjnym i angażującym potencjale. W tym samym czasie (lata 1935-1936) był Polewka kierownikiem literackim, reżyserem i autorem tekstów dla kabaretu „Bury Melonik”, działającego przy Czytelni Towarzyskiej w Krakowie. W sezonie 1937/1938 wspólnie z Józefem Jaremą przygotował słynną szopkę Herod i Ariowie.

W twórczości Polewki dostrzec więc można bardzo charakterystyczne dla dużej grupy utworów i twórców dwudziestolecia międzywojennego połączenie sztuki wyrastającej $\mathrm{z}$ tradycji ludycznej, średniowiecznej w swoim rodowodzie, sztuki igrców, rybałtów, ale i dziadów wędrownych ${ }^{20} \mathrm{z}$ dążeniem do tworzenia sztuki rewolucyjnej, rejestrującej i aktywnie odpowiadającej na zmiany dokonujące się w otaczającym ją środowisku.

To szczególnego rodzaju zwarcie nowoczesnego kabaretu - rozwój którego tłumaczyć można pojawieniem się innego typu odbiorcy, zmianą ocze-

\footnotetext{
18 A. Polewka, Igrce w Barbakanie, s. 8.

19 Tak jak ma to miejsce na przykład w przypadku twórczości Witolda Wandurskiego, Ewy Szelburg-Zarembiny.

20 Szczególnie ciekawe omówienie tego zagadnienia można znaleźć w K. Michajłowa, Dziad wędrowny w kulturze ludowej Słowian, przeł. H. Karpińska, Warszawa 2010.
} 
kiwań, korektą sposobu widzenia świata spowodowaną $\mathrm{w}$ znacznej mierze I wojną światową ${ }^{21}-\mathrm{z}$ tradycjami ludowych igrców, rybałtów, widowisk misteryjnych, ale i to misterium wywracających na opak, wydaje się najpełniej realizować w tradycji samego Cricot I. Na scenie przy ulicy Łobzowskiej stworzono bowiem przestrzeń, w której występy taneczne, popisy Jacka Pugeta, krótkie kabaretowe scenki, funkcjonowały na równych prawach co wystawienia sztuk samego Jaremy, szopki polityczne czy wystawienie spolszczonego przez Polewkę Mistrza Panthelina, a w końcu także spektakl na podstawie $M a$ twy Witkacego. Oprócz tego było tutaj również miejsce na Anno Santo Jalu Kurka czy Reportaż z przedmieścia Ludwika Gołąba ${ }^{22}$. Połączenie kabaretu, szopki, cyrku i misterium w kontekście twórczości dwudziestolecia międzywojennego dalej pozostaje problemem nieopracowanym.

Zjawisko to nie ograniczało się jedynie do twórczości osób współpracujących z Cricot I. Właśnie $\mathrm{w}$ dwudziestoleciu międzywojennym pojawiają się bardzo ciekawe utwory, których autorzy, sięgając do ludyczności, jednocześnie tworzą elitarną sztukę zaangażowaną. To zwarcie ludowości, widowiskowości z politycznością i społecznym rezonowaniem ${ }^{23}$ jest szczególnie trudne do opisania, ale jednocześnie analiza tego fenomenu prowadzić może do przyjęcia zupełnie nowej perspektywy oglądu dorobku takich twórców, jak Józef Jarema, Witold Wandurski, Ewa Szelburg-Zarembina, by wymienić tylko kilka najbardziej wyrazistych postaci, na których koncentruję się $\mathrm{w}$ tym artykule.

Zaskakujące wydaje się, że twórcy dwudziestolecia czerpią z tej samej bogatej tradycji, która przeżywała prawdziwy renesans na przełomie XIX i XX wieku. U twórców młodopolskich znaleźć można szereg utworów ${ }^{24}$,

21 O czym przekonująco pisał M. Eksteins, Święto Wiosny. Wielka Wojna i narodziny nowego wieku, przeł. K. Rabińska, Poznań 2014.

22 Pełną listę spektakli planowanych do wystawienia w Cricot podaje autorka monografii Józefa Jaremy. Zob. J. Mazur-Fedak, Józef Jarema. W międzywojenny teatrze awangardowym Cricot (I), Kraków 2008, s. 90-93.

${ }^{23}$ Wydaje się, że do takiego myślenia o szczególnej linii rozwojowej form dramatycznych uprawnia nie tylko historia komedii dell'arte, rosyjskiego bałaganu czy teatru Pietruszki, niemieckiego Bänkelsang, lecz także tradycji greckich i bizantyjskich mimów. Por. O. Freudenberg, Mim, w: tejże, Obraz i pojęcie, przeł. B. Żyłko, Gdańsk 2007, s. 77-125; A. Somos, Święty Bachus. Nieznane lata teatru greckiego 300 p.n.e. - 1600 n.e., przeł. J. Kruczkowska, R. Lewandowski, B. Schada-Borzyszkowska, Wrocław 2010, s. 31-78.

${ }^{24}$ Głównie zbieranych pod wspólnym terminem baśni dramatycznej: A. Czabanowska-Wróbel, Baśń jako światopogląd. Baśn i baśniowość w twórczości Leśmiana, „Pamiętnik Literacki” 1988, z. 4; R. Waksmund, Młodopolska baśń dramatyczna. Od bajki ludowej do impresji scenicznej (z zagadnień struktury gatunku) w: Baśnie nasze wspótczesne, red. J. Ługowska, Wrocław 2005; M. Nabiałek, Baśń dramatyczna - zapomniane ogniwo, "Zagadnienia Rodzajów Literackich” 2019, z. 3. 
które były silnie zakorzenione w tradycji arlekinady, baśni ludowej, rewii i (co może mniej oczywiste) misterium. Wystarczy wspomnieć tutaj choćby o: Zaczarowanym kole Lucjana Rydla, Erosie i Psyche Jerzego Żuławskiego, Arfie Macieja Szukiewicza, Skrzypku opętanym Bolesława Leśmiana. Utwory te podejmowały bardzo różną tematykę, nie miały jednego typu bohatera, sposób ukształtowania tekstu także $\mathrm{w}$ wielu przypadkach był bardzo indywidualny. Podejrzewać jednak można, że wszystkie te próby teatralne motywowane były szukaniem języka opowieści o świecie pierwotnym, prawdziwym, czystym. Dwudziestolecie natomiast sięga do tej samej tradycji w zupełnie innym celu. Zdaje się także odkrywać inne, angażujące oblicze tego typu sztuki. Tutaj już nie chodzi o mimesis, a diegesis. Liczą się możliwości opowiadania o świecie, jakie daje twórcom tego typu tradycja. Możliwości nawiązania innego kontaktu z odbiorcą, wywrotowy i protestacyjny charakter tej twórczości, w końcu jej zdolność do podważania autorytetów, praw i zasad. Bardzo dobrze pokazuje to wstęp do Igrców w Barbakanie, a więc książkowego zapisu widowiska przygotowanego przez Polewkę w 1938 roku, wystawianego także rok później oraz po II wojnie światowej - w roku 1946 i 1947.

\section{Igrce w Barbakanie}

Adam Polewka w świadomości większości badaczy zajmujących się literaturą dwudziestolecia pozostaje postacią marginalną. Powodem jest przede wszystkim brak większości jego tekstów, szczególnie tych najbardziej interesujących - szopek i rewii politycznych. Po Polewce, który po 1945 roku rozstał się z teatrem na rzecz działalności politycznej (prowadzonej oczywiście także przed wojną), został nam dzisiaj przede wszystkim przekład słynnej średniowiecznej farsy Mistrz Panthelin oraz zapis cieszącego się ogromną popularnością podczas Dni Krakowa wystawienia Igrce w gród wala/Igrce w Barbakanie.

Obydwa utwory wskazują na charakterystyczną cechę twórczości Adama Polewki, jaką było zainteresowanie sztuką średniowieczną, ludową, wyrastającą z pewnych zachowań rytualnych, ale pozwalającą też na translację i reinterpretację z uwzględnieniem współczesnych twórcy problemów. U Polewki już pod koniec lat 20. obserwować można dążenie do zbudowania teatru proletariackiego, masowego, odpowiadającego na potrzeby konkretnego typu odbiorcy, ale i odbiorcę tego zachęcającego do żywego kontaktu z dziełem/widowiskiem ${ }^{25}$. Współbieżne $\mathrm{z}$ tymi założeniami było zainteresowanie

\footnotetext{
${ }^{25}$ Co udało się osiągnąć Polewce zarówno w Teatrze Artystów Cricot, jak i podczas wystawień Igrców.
} 
teatrem średniowiecznym oraz gatunkami takimi jak farsa, szopka czy rewia, a także formami jakoś $\mathrm{z}$ tych tradycji wyrastającymi ${ }^{26}$. Kluczowe jest poszukiwanie formy, która w atrakcyjny, angażujący, a jednocześnie budujący pewną świadomość kulturalną sposób, pomoże opisać rzeczywistość rozgrywającą się "tu i teraz". Wydaje się bowiem, że to tak bardzo zadziwiające nas dzisiaj zafascynowanie dwudziestolecia międzywojennego szopką i kabaretem, wyrastało tyleż z fascynacji dokonaniami teatrów i kabaretów Paryża czy Berlina ${ }^{27}$ oraz rodzącą się w Rosji twórczością proletariacką ${ }^{28}$, co z dostrzeżenia rodzimego źródła, jaką była twórczość rybałtowska i jej późniejsze przetworzenie $\mathrm{w}$ tradycji szopki, której literackim wyrazem było Wesele Stanisława Wyspiańskiego ${ }^{29}$ czy też szerzej - młodopolska baśń dramatyczna. Pod tym względem twórczość Polewki jest bardzo wyrazista, a jednocześnie jak w soczewce skupia tendencje, które obserwować można także u innych twórców tego okresu.

Zamiłowanie Polewki do tego średniowiecznego teatru ujawniało się oczywiście wcześniej - choćby w szopce Herod $i$ Ariowie ${ }^{30}$ - natomiast pełny wyraz z pewnością znalazło $\mathrm{w}$ stworzonym przez niego widowisku scenicznym Igrce w gród walq wystawionym, jak już wspomniałam, w 1938 roku podczas Dni Krakowa, których Polewka (wspólnie z historykiem Jerzym Dobrzyckim ${ }^{31}$ ) był inicjatorem. Sam zagrał w nim rolę Marchołta.

${ }^{26} \mathrm{Na}$ trop ten naprowadza jedna z opowieści poświęcona Adamowi Polewce, którą przytacza Anna Grochowska: „Prężnie działając w Krakowskim Oddziale ZLP [już po wojnie - dop. M.N.], nadal interesował się teatrem. Pewnego razu po przedstawieniu Mirandoliny Carla Goldoniego Polewka przyszedł na zebranie do stołówki [w Domu Literatów przy Krupniczej - dop. M.N.] znakomicie przygotowany. W swoim długim, wyczerpującym, krytycznym wystąpieniu potępił między innymi kostiumy aktorek, które - jego zdaniem - nazbyt odsłaniały biusty. Na tę wieść zebrani wybuchnęli gromkim śmiechem. Polewka, zniesmaczony ignorancją słuchaczy, objaśnił: «Nie śmiejcie się, wiem, co mówię, bo długo w tym materiale grzebałem»" [A. Grochowska, Wszystkie drogi prowadza na Krupniczą. O Domu Literatów, Kraków 2017, s. 153].

27 Bardzo ciekawych inspiracji dostarcza praca Lucjana Puchalskiego, wiążącego niemiecką tradycję kabaretową z twórczością średniowieczną. Zob. L. Puchalski, Kabaretowy świat. Estetyczne dziedzictwo kabaretu w literaturze Republiki Weimarskiej, Wrocław 1991.

28 Por. K. Osińska, Ewolucja radzieckich widowisk masowych (do lat trzydziestych XX wieku), w: Teatr masowy. Teatr dla mas, red. M. Leyko, Łódź 2011, s. 207-240.

29 Bardzo cennych wskazówek, które jednak nie doczekały się rozwinięcia, dostarcza w tej kwestii praca Marii Renaty Mayenowej. Zob. R. Kapłanowa [M.R. Mayenowa], „Wesele" Stanisława Wyspiańskiego. Problemy kompozycji, oprac. M. Prussak, Warszawa 2013.

30 Więcej o twórczości Polewki znaleźć można we wspomnieniach osób związanych z Cricot I. Zob. S. Żytyński, Szopki Adama Polewki, w: Cyganeria i polityka. Wspomnienia krakowskie 1919-1939, red. K. Bidakowski, Warszawa 1964.

31 Warto przypomnieć, że ten sam Dobrzycki przyczynił się także do ustanowienia słynnego konkursu szopek krakowskich. 
Nie na samym widowisku chciałabym się jednak tutaj skupić, lecz na odautorskim wstępie, który zdaje się naprowadzać na kilka istotnych tropów dotyczących sposobu rozumienia i funkcjonalizacji tradycji ludowych widowisk w dwudziestoleciu międzywojennym.

Po wprowadzeniu dotyczącym specyfiki Krakowa jako miejsca szczególnie sprzyjającego wystąpieniom igrców ${ }^{32}$ Polewka zaczyna prezentować tę sztukę i jej charakter, wskazując, że "twórczość ludowa przejawiała się w tego rodzaju widowiskach, obok sztuki cyrkowej i pieśniarstwa przede wszystkim w farsach i wesołych, satyrycznych gadkach" [podkr. - M.N.] ${ }^{33}$. Tłumacz Mistrza Panthelina wyraźnie sygnalizuje różnorodność form widowiskowych związanych w praktykami igrców. Tym samym wskazuje na te, które odnaleźć można w bardzo wielu utworach dwudziestolecia międzywojennego, niekoniecznie wprost realizujących poetykę szopki czy kabaretu. O obecności cyrku w twórczości dramatycznej lat 20. i 30. kilkukrotnie już pisano ${ }^{34}$, nie są to jednak próby roszczące sobie prawo do ujęć monograficznych. Podobnie jest $\mathrm{z}$ opracowaniem sposobów wykorzystania farsy ${ }^{35}$ i szopki. Realizacji tych różnoimiennych tradycji doszukiwać się natomiast można (na różnych oczywiście poziomach) w twórczości Picadora czy Cricot I, ale też Jalu Kurka, Tytusa Czyżewskiego, Witolda Wandurskiego, Ewy Szelburg-Zarembiny, Andrzeja Rybickiego, Ludwika Morstina i wielu innych.

Co decydowało o tak wielkiej popularności tych form? Odpowiedzi można szukać w kolejnych fragmentach wywodu Polewki:

Wykpiwali w nich waganci nie tylko możnych, ale często i najmożniejszych ówczesnego świata, nie tylko niechętnych im spasionych rajców miejskich i ich ratuszne sługi, ale i głowom koronowanym przyszywali łatki, a także hierarchii kościelnej, łącznie z papieżem nie szczędzili. Bywało, że ledwie przybyli do miasta, a już po jednym dniu pobytu w nim pochwytawszy $w$ gospodach narzekania i wymyślania na feudalnych zdzierców, świeckich czy duchownych - składali szybko "ucieszne gadki" lub improwizowali dialogi, czy nawet coś w rodzaju fars [podkr. - M.N.] ${ }^{36}$.

32 Trop ten zresztą warto mieć także na uwadze, zastanawiając się nad szczególną geopoetyką form dramatycznych $\mathrm{w}$ dwudziestoleciu międzywojennym.

33 A. Polewka, Igrce w Barbakanie, s. 6.

34 Por. M. Leyko, Dwudziestowieczna awangarda teatralna a cyrk, w: Nie tylko klaun i tygrys. Szkice o sztuce cyrkowej, red. M. Leyko, Z. Snelewska-Stempień, Łódź 2019, s. 113-124; P. Stangret, Awangardowa rehabilitacja cyrku, w: Cyrk w świecie widowisk, red. G. Kondrasiuk, Lublin 2017, s. $135-146$.

35 Por. M. Rawiński, Między misterium i farsą. Polska dramaturgia międzywojenna w kontekście europejskim, Lublin 1986.

36 A. Polewka, Igrce w Barbakanie, s. 6. 
Fragment ten, nie tylko wyraźnie nakierowuje uwagę na różnorodność form, którymi posługują się igrce, ale wskazuje też na ich, bardzo istotną z mojego punktu widzenia, cechę. Chodzi o zdolność do wchłaniania różnych języków, dyskursów, światopoglądów. Można pokusić się więc o tezę, że między innymi ta właściwość widowiskowych gatunków o silnej proweniencji ludycznej sprawiła, że twórcy dwudziestolecia tak chętnie po nie sięgali. To właśnie szopki, farsy, „ucieszne gadki” czy improwizowane dialogi pozwalały na tworzenie sztuki, w ramach której dochodziło do ścierania się odmiennych światopoglądów i świata-wyglądów.

Fascynacja tym, co ludowe albo za ludowe uznawane, związane tyleż z opisywaniem rzeczywistości za pomocą prawideł, porzekadeł, przysłów i pieśni, co z jej oswajaniem z pomocą ludowej kultury śmiechu, nie sprowadza się $w$ dwudziestoleciu międzywojennym do ślepego naśladownictwa (co można byłoby zarzucać niektórym twórcom z okresu Młodej Polski). Te średniowieczne, ludowe widowiska stały się dla Polewki, Jaremy, Wandurskiego, Kurka formą, w którą wlana została zupełnie nowa treść. Pozwalały tworzyć ramę, rozciągać tło, na którym dochodziło do podważenia, reinterpretacji, rekontekstualizacji dotychczas obowiązujących stylów myślenia.

Dokąd to miało prowadzić? Na to pytanie również we wstępie Polewki można znaleźć odpowiedź. Co ciekawe, wskazuje na nią fragment zgoła genologiczny:

Słowo farsa, w staropolszczyźnie "krotochwila”, pierwotnie oznaczało wstawkę w tekście kościelnym. Już w VII wieku spotyka się tzw. epistolae cum farsa. Od wieku XII na zachodzie Europy farsa oznacza wstawkę do widowiska dramatycznego o charakterze religijnym. Z czasem farsa rozrośnie się i usamodzielni tak, że stanie się tekstem osobnych przedstawień i fundamentem sceny świeckiej ${ }^{37}$.

Związek farsy i sztuki religijnej nie jest oczywiście nowym literaturoznawczym faktem, choć wydaje się, że szczególnie w odniesieniu do relacji między sztuką mimu (także mimu literackiego) a misterium potrzebne są dzisiaj znacznie bardziej pogłębione badania. Na tym etapie rozważań warto jednak dostrzec bardzo charakterystyczne dla polskiej twórczości dramatycznej dwudziestolecia międzywojennego splecenie misterium, baśni dramatycznej i farsy (początków tego typu eksperymentów można szukać już w Młodej Polsce - przykładem choćby Arf Macieja Szukiewicza). Wydaje się bowiem, że zwarcie to wskazuje na inną bardzo ważną cechę twórczości lat 20. i 30. - poszukiwanie nowej formuły dla moralno-społecznych rozważań.

37 Tamże, s. 7. 
Okazało się, że to właśnie szopka, cyrk i farsa wtłoczone w tradycyjne formy dramatyczne pozwalają jednocześnie rozbijać od środka skorupę dramatu, prowadzić aktualną dyskusję społeczno-polityczną (czasem literacką, jak choćby w przypadku Rzeczpospolitej poetów Ludwika Morstina), jak i stawiać fundamentalne pytania o zagadnienia moralne. W kontekście Igrców Polewki jest to szczególnie dobrze widoczne:

Nigdy nie brakowało „Igrcom” tzw. aktualnych momentów. Kiedy w roku 1938 pojawili się po raz pierwszy na scenie radni: Wozibrzuch, Chudogęba i Odmikufel w farsie „Jak Sowizdrzała obwieścić rajcują - rajce w Rakowie, gdzie raki zimują", kiedy rozmawiali o tym, jak to "rączka rączkę myje” i zgodzili się skwapliwie, że jest to „rzecz niesłychana w Rakowa dziejach - nie dbać o swego złodzieja" - trzej sanacyjni radni miejscy zerwali się z miejsc i... opuścili widownię, żegnani śmiechem publiczności. Właśnie mniej więcej w tym czasie wyszły na jaw "domowe pożytki” w magistracie krakowskim. [...]

W roku 1939 [...] śpiewano w Barbakanie pieśń o skardze Wisły oraz „O króla Jagiełłowych rycerskich gestach", a Marchołt "gruby a sprośny" szubienicę Krzyżakom przepowiadał. Działo się to na dwa miesiące przed wybuchem wojny i wejściem wojsk hitlerowskich do Krakowa ${ }^{38}$.

Dramatyczność tej wyjątkowej aktualizacji Igrców Polewka podkreślał zresztą we wstępie do wydania książkowego kilkukrotnie:

W roku 1939 tekst Igrców został rozbudowany. Wystąpił nawet sprośny Marchołt z antyhitlerowskimi gadkami. Lirnik śpiewał pieśń "Jak się Wisła skarży i płacze u Gdańska"... Mówiono i śpiewano o Krzyżakach. Historia zdawała się powtarzać... W dniu 4 sierpnia 1939 roku przemówiłem na pożegnanie do publiczności, rzutując ogólnie wydarzenia, które miały nadejść. Mówiłem o burzy wojennej, która nadciągała ${ }^{39}$.

Trzeba zresztą podkreślić, że analogicznymi chwytami Polewka posługiwał się m.in. w szopce Herod i Ariowie, o której wiemy najwięcej dzięki recenzji Ludwika Pugeta ${ }^{40}$, mimo że skupiała się ona przede wszystkim na kwestiach formalnych. Zdaniem Karoliny Czerskiej możliwe jest:

że autor recenzji nie odniósł się do treści przez wzgląd na cenzurę, która i tak nie była łaskawa dla tekstu Polewki - wycięto między innymi fragmenty o ministrze Józefie Becku, który śpiewał o żalach Wisły płynącej nie do Gdańska, lecz „nach Danzing" [...]. Bodaj najostrzejszym pomysłem Polewki w tym przedstawieniu było wprowadzenie motywu radia z polskiej kolonii Negropol ${ }^{41}$.

\footnotetext{
38 Tamże, s. 15.

39 Tamże, s. 13.

40 L. Puget, Szopki krakowskie, „Kurjer Poranny” 1938, nr 46, s. 8.

41 K. Czerska, Cricot - marzenie o teatrze politycznym? (Fragmenty), s. 340.
} 
Polewka nie stronił także od aktualizacji wykraczających poza problemy krajowe: o zajęciu przez Włochy Etiopii opowiadała Szopka abisyńsko-krakowska.

Powrócić jednak warto do tego moralno-społecznego splecenia, które charakteryzuje twórczość dramatyczną dwudziestolecia międzywojennego. Polewka o średniowiecznych formach teatralnych pisze tak:

Średniowieczny moralitet i niemoralna czy amoralna farsa średniowiecza to dwie strony tego samego medalu, dwa janusowe oblicza średniowiecznej moralności, opartej na religijnych nakazach i sankcjach pozaświatowych ${ }^{42}$.

W dwudziestoleciu obie formy zdają się łączyć w jakiś nierozerwalny węzeł. Te dwa oblicza w twórczości Jaremy, Polewki, Wandurskiego, Szelburg-Zarembiny wzajemnie się przenikają. Sięgnięcie po wyrazisty kod kulturowy, jaki stanowiła forma igrców, fars czy szopek i wykorzystanie jej do opowiadania o nowej rzeczywistości sprawiło, że w utworach tych współbrzmiały idealnie dwa głosy. To zaś pozwalało pokazywać rzeczywistość w podwójnym odbiciu. Szopkowość zaś czy pewnie częściej wykorzystywana w odniesieniu do dramatu dwudziestolecia międzywojennego kabaretowość to zjawiska tyleż popularne, co nieopisane. O ile z historycznego punktu widzenia o obecności rewii, kabaretu, szopki czy cyrku w kulturze polskiej lat 20.-30. XX wieku coś nieco już wiemy, o tyle krytyczno-teoretyczny namysł nad tym zjawiskiem dalej wydaje się niewystarczający. Trudno wyjaśnić tak silną obecność widowiskowych, ale i popularnych form teatralnych czy parateatralnych fascynacją wizualnością, którą oczywiście ujawniali twórcy dwudziestolecia, ale która nie wydaje się głównym powodem sięgania do tego typu utworów. Trudno także to ponadprzeciętne zainteresowanie interpretować wyłącznie w kontekście fascynacji kulturą popularną. Wytłumaczenia szukać chyba można natomiast w wyjątkowej dwu- lub wielogłosowości, jaką oferowały tego typu formy widowiskowe. Polifoniczność dramatu dwudziestolecia wydaje się zaś wręcz koniecznością, jeśli pomyśleć o tym, jaką dyskusję ze światem przyszło prowadzić działającym wtedy twórcom.

\section{Bibliografia}

Czabanowska-Wróbel Anna (1988), Baśń jako światopoglad. Baśń i baśniowość w twórczości Leśmiana, „Pamiętnik Literacki”, z. 4, s. 29-62.

42 A. Polewka, Igrce w Barbakanie, s. 8. 
Czerska Karolina (2021), Cricot - marzenie o teatrze politycznym? (Fragmenty), w: Polityki Awangardy, red. A. Karpowicz, J. Kornhauser, M. Rakoczy, A. Wójtowicz, Kraków: Wydawnictwo Uniwersytetu Jagiellońskiego, s. 331-342.

Czerska Karolina (2019), Teatr Cricot - suma przybliżeń, „Didaskalia”, nr 153, s. 46-54.

Dorak-Wojakowska Lilianna (2019), Dramaturg jako archiwista. O stylu montażu dokumentalnego Witolda Wandurskiego... i sceny robotniczej, "Annales Universitatis Paedagogicae Cracoviensis. Studia de Cultura", nr 11, s. 20-35.

Duniec Krystyna (2017), Dwudziestolecie. Przedstawienia, Warszawa: Instytut Teatralny im. Zbigniewa Raszewskiego, Instytut Sztuki PAN, SWPS Uniwersytet Humanistycznospołeczny.

Eksteins Modris (2014), Święto Wiosny. Wielka Wojna i narodziny nowego wieku, przeł. K. Rabińska, Poznań: Wydawnictwo Zysk i S-ka.

Fox Dorota (2013), Czasopiśmiennictwo teatralne w Polsce w latach 1918-1939, Katowice: Wydawnictwo Uniwersytetu Śląskiego.

Freudenberg Olga (2007), Mim, w: O. Freudenberg, Obraz i pojęcie, przeł. B. Żyłko, Gdańsk: Wydawnictwo Uniwersytetu Gdańskiego.

Grochowska Anna (2017), Wszystkie drogi prowadzą na Krupniczą. O Domu Literatów, Kraków: Księgarnia Akademicka.

Jarema Józef (1934), Cricot. O teatrze plastycznym, "Głos Plastyków”, nr 7-8.

Jarema Józef (1934), Patrzymy na was, „Tygodnik Artystów”, nr 3.

Jarema Józef (1938), Przed nowym sezonem Cricot, „Nasz Wyraz”, nr 9, s. 7.

Kapłanowa Rachela [Mayenowa Maria Renata] (2013), „Wesele” Stanisława Wyspiańskiego. Problemy kompozycji, oprac. M. Prussak, Warszawa: Wydawnictwo IBL PAN.

Kydryński Juliusz (1964), Próba portretu (Rzecz o Adamie Polewce), Kraków: Wydawnictwo Literackie.

Lau Jerzy (1967), Teatr artystów Cricot, Kraków: Wydawnictwo Literackie.

Leyko Małgorzata (2019), Dwudziestowieczna awangarda teatralna a cyrk, w: Nie tylko klaun i tygrys. Szkice o sztuce cyrkowej, red. M. Leyko, Z. Snelewska-Stempień, Łódź: Wydawnictwo Uniwersytetu Łódzkiego, s. 113-124.

Marczak-Oborski Stanisław (1973), Teatr romantyczny, rewolucyjny, polityczny, „Teksty”, nr 3, s. 52-67.

Mazur-Fedak Jolanta (2008), Józef Jarema. W międzywojenny teatrze awangardowym Cricot (I), Kraków: Universitas.

Michajłowa Katia (2010), Dziad wędrowny w kulturze ludowej Słowian, przeł. H. Karpińska, Warszawa: Oficyna Naukowa.

Nabiałek Magda (2019), Baśń dramatyczna - zapomniane ogniwo, „Zagadnienia Rodzajów Literackich", t. 62, z. 3, s. 103-119.

Osińska Katarzyna (2011), Ewolucja radzieckich widowisk masowych (do lat trzydziestych XX wieku), w: Teatr masowy. Teatr dla mas, red. M. Leyko, Łódź: Wydawnictwo Uniwersytetu Łódzkiego, s. 207-240.

Pol Stefan (1987), Ze wspomnień nauczyciela socjalisty, w: PPS - wspomnienia z lat 1918-1939, t. 2, red. J. Cesarski i in., Warszawa: Książka i Wiedza.

Polewka Adam (1938), Herod i Ariowie (fragment z szopki „żywych masek”), „Nasz Wyraz", nr 1 . 
Polewka Adam (1953), Igrce w Barbakanie, Kraków: Wydawnictwo Literackie. Polewka Adam (1955), Kocham i nienawidzę, Kraków: Wydawnictwo Literackie. Puchalski Lucjan (1991), Kabaretowy świat. Estetyczne dziedzictwo kabaretu w literaturze Republiki Weimarskiej, Wrocław: Wydawnictwo Uniwersytetu Wrocławskiego.

Puget Ludwik (1938), Szopki krakowskie, „Kurjer Poranny”, nr 46, s. 8.

Rawiński Marian (1986), Między misterium i farsa. Polska dramaturgia międzywojenna w kontekście europejskim, Lublin: Uniwersytet Marii Curie-Skłodowskiej, Wydział Humanistyczny.

Somos Aleksij (2010), Święty Bachus. Nieznane lata teatru greckiego 300 p.n.e. - 1600 n.e., przeł. J. Kruczkowska, R. Lewandowski, B. Schada-Borzyszkowska, Wrocław: Instytut im. Jerzego Grotowskiego.

Waksmund Ryszard (2005), Młodopolska baśn dramatyczna. Od bajki ludowej do impresji scenicznej (z zagadnień struktury gatunku) w: Baśnie nasze współczesne, red. J. Ługowska, Wrocław: Biblioteka Literatury Ludowej.

Stangret Paweł (2017), Awangardowa rehabilitacja cyrku, w: Cyrk w świecie widowisk, red. G. Kondrasiuk, Lublin: Warsztaty Kultury w Lublinie, s. 113-124.

Wiciński Henryk (1934), Nowy sezon Cricot w Krakowie, „Gazeta Artystów”, nr 7, s. 1-2. Wodnarowie Estera i Mieczysław (1974), Polskie sceny robotnicze 1918-1939. Wybór dokumentów i relacji, Warszawa: Państwowy Instytut Wydawniczy.

Żytyński Stanisław (1964), Szopki Adama Polewki, w: Cyganeria i polityka. Wspomnienia krakowskie 1919-1939, red. K. Bidakowski, Warszawa: Czytelnik.

\title{
The Jugglers Play at Drama:
}

\section{Adam Polewka and the Farce Inspiration in the Dramaturgy of the Interwar Period}

\begin{abstract}
The article reflects on the connections between the Polish drama of the interwar period with such stage performances as a nativity play, farce, cabaret, and circus. The text attempts to point to the possible inquiries into this important problem of the dramaturgy of the 1920s and 1930s. The author concentrates on Adam Polewka himself and his political farse plays, especially the record of Igrce w Barbakanie, a performance prepared for the Cracow Days in 1938. She reads critically the introduction to the post-war edition of this text. In her opinion, this authorial commentary includes precious information about such stage forms of the interwar period as a farse play and circus.
\end{abstract}

Keywords: drama, cabaret, farse play, igrce, interwar period 